\title{
The Speech Act of Complaining in Japanese Anime
}

\author{
Laras Wibawati Citra, Idah Hamidah, Dian Bayu Firmansyah* \\ Jurusan Bahasa \& Sastra Asia Timur, Program Studi Sastra Jepang, Universitas Jenderal Soedirman, Purwokerto, Indonesia \\ dbayuf@unsoed.ac.id
}

\begin{abstract}
A B S T R A C T
The purpose of this research is to find out the form of speech act of complaint by children character on "Stand by Me Doraemon" film and to describe complaint strategy that is used by the children to older people and among children. This research used illocutionary speech acts theory by Searle (1975) and theory of complaint strategies by Trosborg (1995). This research used descriptive qualitative method. The results found 30 data containing complaints by children's character to older people and among children either directly or indirectly. Based on Trosborg classifications, the complaint strategies found in this study can be categorized into four categories, including complaint strategy with no explicit reproach (4 data), complaint strategy with expression of annoyance or disapproval (17 data), complaint strategy with accusation (1 data), and complaint strategy with blaming ( 8 data). The findings also showed that the children character on this film mainly use complaining strategies with expression of annoyance or disapproval.
\end{abstract}

Speech act; Illocutionary act; Complaint strategy; Children; Film

\section{K E Y W O R D S}

A R T I C L E I N F O

First received: 21 September $2020 \quad$ Final proof accepted: 25 November 2020

Available online: 31 December 2020

\section{PENDAHULUAN}

Sebagai makhluk sosial, manusia pasti membutuhkan manusia lainnya dalam beberapa hal tertentu. Manusia dalam menjalani perannya memerlukan sebuah simbol untuk mengkomunikasikan segala pemikiran dan perasaannya yang dimiliki. Bahasa merupakan alat komunikasi yang paling efektif untuk berinteraksi dengan orang lain.

Bahasa yang digunakan sebagai alat komunikasi sehari-hari terbagi menjadi dua sarana, yaitu bahasa lisan dan bahasa tulisan.
Bahasa lisan adalah bahasa yang diucapkan dan merupakan hubungan atau komunikasi secara langsung, sedangkan bahasa tulisan adalah rekaman visual dalam bentuk huruf-huruf dan tanda-tanda baca dari bahasa lisan dan merupakan hubungan atau komunikasi secara tidak langsung.

Komunikasi dapat berjalan dengan baik bila bahasa yang digunakan dapat dimengerti oleh penutur maupun mitra tutur. Oleh karena itu, penutur maupun mitra tutur harus mampu menginterpretasikan makna yang terkandung dalam sebuah komunikasi. Ilmu yang digunakan untuk mempelajari tentang makna terkandung dalam ilmu pragmatik. 
Yule (2006) mengungkapkan bahwa pragmatik adalah studi tentang makna yang disampaikan oleh penutur atau penulis dan ditafsirkan oleh pendengar atau pembaca. Pragmatik merupakan ilmu yang mengkaji mengenai makna kalimat yang diucapkan/dituturkan oleh pembicara/ penutur kepada pendengar/mitra tutur dan kemudian disesuaikan dengan konteks serta situasi yang sedang berlangsung

Salah satu hal yang paling penting dalam interpretasi percakapan secara pragmatik adalah konsep tindak tutur (Nurgiyantoro, 2002). Penutur berusaha mengungkapkan dirinya kepada mitra tutur, mereka tidak hanya menghasilkan tuturan yang mengandung kata-kata dan struktur-struktur gramatikal saja, tetapi mereka juga memperlihatkan tindakan-tindakan melalui tuturan-tuturan itu (Yule, 2006). Tindakantindakan yang dilakukan atas dasar tuturantuturan tersebut dinamakan tindak tutur.

Searle membagi tindak tutur menjadi tiga jenis tindakan yang berbeda, yaitu tindak lokusioner 'locutionary act', tindak ilokusioner 'illocutionary act', dan tindak perlokusioner 'perlocutionary act' (Searle dalam Nadar, 2013). Tindak lokusioner adalah tindak tutur yang semata-mata menyatakan sesuatu, sedangkan tindak ilokusioner adalah apa yang ingin dicapai oleh penuturnya pada waktu menuturkan sesuatu dan dapat merupakan tindakan menyatakan, berjanji, meminta maaf, mengancam, meramalkan, memerintah, meminta, dan lain sebagainya. Jenis tindak tutur lain adalah tindak perlokusioner, yaitu tindakan untuk mempengaruhi lawan tutur seperti memalukan, mengintimidasi, membujuk, dan lain-lain.

Searle dalam Nadar (2013) mengklasifikasikan tindak tutur ilokusi dibedakan menjadi 5 jenis berdasarkan tujuan si penutur, yaitu tindak tutur asertif (assertives), direktif (directives), komisif (commisives), ekspresif (expressives), dan deklaratif (declarations) (Searle dalam Leech, 1993). Hal yang membuat penulis tertarik untuk memilih menggunakan teori tindak tutur ilokusi karena tindak tutur ilokusi merupakan tindakan melakukan sesuatu yang mempunyai maksud dan fungsi tertentu dan hal tersebut berkaitan dengan penelitian penulis. Jenis tindak tutur yang termasuk dalam kelompok ini dan akan dibahas oleh penulis adalah mengeluh (complaint).

Dalam penelitian bidang linguistik, dapat menggunakan film atau drama sebagai sumber data. Sehingga penulis menggunakan film Stand by Me Doraemon sebagai sumber data dari penelitian penulis.
Penelitian ini terfokus kepada tindak tutur mengeluh yang dilakukan oleh tokoh anak-anak terhadap orang tua dan anak terhadap teman sebayanya di film Stand by Me Doraemon. Film tersebut mengandung banyak makna dan tuturan mengeluh yang dilakukan oleh tokoh anak-anak terutama oleh pemeran utama, yaitu Nobita. Oleh karena itu, penulis tertarik untuk meneliti bagaimana bentuk tindak tutur mengeluh yang muncul di dalam film tersebut dan strategi yang digunakan oleh penutur dalam mengungkapkan keluhannya tersebut kepada mitra tutur yang merupakan teman sebaya dan kepada mitra tutur yang lebih tua.

Berikut ini merupakan contoh tuturan mengeluh yang dimaksud.

Situasi Tuturan: Percakapan antara Mama dan Nobita, pagi hari di rumah Nobita. Saat itu Nobita sedang tidur dan Mamanya membangunkan Nobita yang sudah kesiangan untuk berangkat sekolah.

$\begin{array}{cl}\text { Mama } & \text { : Iikagenni okinasai! } \\ \text { Nobita } & \text { Cepat bangun! } \\ & \text { mande motto hayaku okoshitekurenaino } \\ & \text { Kenapa tidak } \\ & \text { membangunkan aku lebih cepat! } \\ & \text { (Stand by Me Doraemon, menit ke 00.01.23) }\end{array}$

Tuturan di atas menyampaikan keluhan Nobita karena dia bangun kesiangan. Pada situasi di atas, Nobita yang bangun kesiangan menunjukkan keluhannya kepada mamanya. Dia berpikir bahwa dia kesiangan karena mamanya tidak membangunkannya lebih awal.

Kata yang menunjukkan keluhan adalah "Hayaku okoshitekurenainno" "mengapa tidak membangunkanku lebih cepat?" Hal tersebut tampak pada pertanyaan "Nande" yang dilontarkan oleh Nobita dengan ekspresi kaget setelah melihat jam yang menandakan dia kesiangan. Kemudian dilanjutkan dengan "Okoshitekurenai" yang berarti "tidak membangunkanku". Lalu di akhir kalimat terdapat partikel no yang memberikan nuansa penekanan pada pertanyaan, dimana Nobita meyakini bahwa mamanya benar-benar tidak membangunkan Nobita lebih awal. Strategi keluhan yang digunakan pada percakapan di atas adalah strategi dengan menyalahkan tindakan (orang). 
Hal-hal yang mengakibatkan keluhan tersebut yang menjadi dasar penulis untuk meneliti seperti apa macam-macam bentuk tuturan mengeluh yang dilakukan oleh anak-anak dan strategi yang digunakan untuk mengungkapkan keluhan dalam bahasa Jepang. Sesuai dengan latar belakang di atas, penelitian ini difokuskan pada strategi yang dipakai dan bentuk tindak tutur mengeluh yang digunakan baik secara langsung maupun tidak langsung.

\section{Penelitian Terdahulu}

Penelitian mengenai tindak tutur ilokusi terdapat dalam Nurhasanah (2010) yang mendeskripsikan tindak tutur mengeluh secara langsung yang cenderung dilakukan oleh penutur yang status sosialnya lebih tinggi dari mitra tutur, baik hubungannya di antara mereka akrab ataupun tidak. Tuturan mengeluh yang mereka gunakan adalah strategi keluhan isyarat, keluhan dengan menyalahkan kekesalan, dan keluhan dengan cara menyalahkan. Sedangkan penutur yang status sosialnya lebih rendah dari mitra tutur melakukan tindak tutur mengeluh dengan isyarat, kekesalan, dan menyalahkan. Strategi keluhan isyarat dilakukan karena hubungan di antara mereka tidak akrab. Sedangkan strategi keluhan dengan cara menyalahkan dilakukan karena hubungan yang terjalin di antara mereka akrab. Strategi-strategi yang digunakan oleh penutur bahasa Jepang di dalam drama seri Jepang yang berjudul Shokojo Seira dalam mengungkapkan keluhannya menggunakan pendekatan sosiopragmatik yang dikaitkan dengan konsep strategi mengeluh Anna Trosborg. Metode yang digunakan dalam penelitiannya adalah metode teknik kepustakaan, sedangkan metode penulisan yang dilakukan menggunakan metode eksposisi.

Winoto dan Bayu (2012) meneliti tindak tutur mengeluh berdasarkan tokoh wanita protagonis dan tokoh pria protagonis yang terdapat dalam film Great Teacher Onizuka. Dalam penelitiannya, Winoto dan Bayu (2012) menemukan bahwa complainer pria cenderung menggunakan strategi Annoyance karena strategi tersebut bersifat spontan dan merupakan strategi yang paling mudah dituturkan untuk mengekspresikan perasaan complainer yang buruk dan tidak baik. Sementara itu complainer wanita cenderung menggunakan strategi Ill Consequence karena sifat tokoh Fuyutsuki yang cenderung halus dan sopan, maka sebelum menuturkan keluhannya ia akan berpikir dahulu mengenai konsekuensi buruk yang akan ia hadapi. Dalam penelitiannya, Winoto dan Bayu (2012) menganalisis tindak tutur mengeluh dengan teori Austin dan Searle lalu mengkaitkannya dengan teori strategi mengeluh Anna Trosborg.

Benning dan Parwati (2018) menyatakan bahwa tindak tutur mengeluh yang dilakukan oleh anak-anak secara langsung, baik anak kepada orang tua maupun anak terhadap anak lainnya, hubungan sosial antara penutur dan mitra tutur sangat berpengaruh dalam pemilihan strategi mengeluh. Hasil yang ditemukan menunjukkan 3 strategi mengeluh yang digunakan oleh tokoh dalam drama yaitu strategi keluhan tidak langsung (isyarat), strategi keluhan dengan menyatakan kekesalan, dan strategi keluhan dengan cara menyalahkan. Sumber data yang digunakan dalam penelitian tersebut adalah serial drama yang berjudul Suki $\mathrm{Na}$ Hito $\mathrm{Ga}$ Iru Koto. Dalam penelitiannya, Hadi menganalisis tindak tutur mengeluh dengan pendekatan pragmatik dan mengkaitkannya dengan teori strategi mengeluh Anna Trosborg.

Aprianti (2018) mendeskripsikan penggunaan tindak tutur ilokusi direktif "memerintah" dalam drama Kodo Buru - Dokuta Heri Kinkyu Kyumei. Penelitian ini merupakan penelitian deskriptif kualitatif dan menggunakan teknik simak catat untuk pengumpulan data.

Berdasarkan ketiga penelitian terdahulu, ada beberapa kesamaan yang terdapat dalam penelitian penulis yang terletak pada objek kajian yaitu tindak tutur dan strategi mengeluh menggunakan teori Anna Trosborg, lalu yang membedakan penelitian penulis dengan penelitian terdahulu adalah penulis fokus kepada tindak tutur mengeluh secara langsung maupun tidak langsung yang dilakukan oleh tokoh anak-anak kepada orang tua maupun orang teman sebayanya dalam film Stand by Me Doraemon.

\section{Tindak Tutur}

Searle dalam Nadar (2009) mengungkapkan bahwa unsur paling kecil pada suatu proses komunikasi adalah tindak tutur seperti menyatakan, membuat pernyataan, memberi perintah, menguraikan, menjelaskan, meminta maaf, berterimakasih, mengucapkan selamat, dan lain-lain.

Chaer (1995) berpendapat bahwa tindak tutur adalah makna dari bentuk kalimat yang membedakan lokusi, ilokusi, perlokusi dan mengikuti situasi dalam penentuan makna bahasa. 
Teori tindak tutur memusatkan perhatian pada penggunaan bahasa mengkomunikasikan maksud dan tujuan pembicara. Tindak tutur adalah makna dari bentuk kalimat yang membedakan lokusi, ilokusi, perlokusi, dan mengikutsertakan situasi dalam penentuan makna bahasa. Teori tindak tutur memusatkan perhatian pada cara penggunaan bahasa dalam mengkomunikasikan maksud dan tujuan tuturan.

$$
\text { Kasher dalam Putrayasa (2014) }
$$

mengemukakan bahwa secara pragmatis setidaktidaknya terdapat tiga jenis tindakan yang dapat diwujudkan oleh seorang penutur, yakni tindak lokusi (locutionary act), tindak ilokusi (illocutionary act), dan tindak perlokusi (perlocutionary act). Pertama, tindak tutur lokusi (hatsuwa koui) ialah tindak tutur yang menyatakan sesuatu dalam arti 'berkata' atau tindak tutur dalam bentuk kalimat yang bermakna dan dapat dipahami. Tindak tutur lokusi mengacu pada tindakan penutur dalam mengucapkan sesuatu (The Act of Saying Something). Kedua, tindak tutur ilokusi (hatsuwa naikou) ialah tindakan melakukan sesuatu yang mempunyai maksud dan fungsi tertentu atau dapat dikatakan The Act of Doing Something. Tindak tutur ilokusi berfungsi menyampaikan sesuatu dengan maksud untuk melakukan tindakan yang ingin dicapai oleh penutur pada waktu menuturkan sesuatu kepada mitra tuturnya.

Menurut Searle dalam Leech (1993) tindak tutur ilokusi berdasarkan tujuan si penutur, yaitu sebagai berikut:

1. Asertif (Assertives)

Pada tindak tutur ini penutur terikat pada kebenaran proposisi yang diungkapkan misalnya, menyatakan, menyebutkan, menunjukkan, melaporkan.

2. Direktif (Directives)

Pada tindak tutur ini bertujuan menghasilkan suatu efek berupa tindakan yang dilakukan mitra tutur ilokusi ini, misalnya memesan, memerintah, memohon, menuntut, memberi nasehat.

3. Komisif (Commissives)

Pada tindak tutur ini, mengikat penuturnya untuk melaksanakan apa yang disebut di dalam ujarannya. Misalnya berjanji, bersumpah, mengancam.

4. Ekspresif (Expressives)

Tindak tutur yang dilakukan dengan maksud agar ujarannya diartikan sebagai evaluasi tentang hal yang disebutkan dalam ujaran tersebut. Misalnya mengeluh, memuji, mengucapkan terima kasih, mengkritik.

\section{Deklarasi (Declarations)}

Tindak tutur deklarasi merupakan tindak tutur yang dilakukan si penutur dengan maksud untuk menciptakan hal (status, keadaan, dan sebagainya) yang baru. Misalnya memutuskan, membatalkan, melarang, mengizinkan, memberi maaf.

Menurut linguistik, tindak ilokusi dapat dilakukan dengan dua acara yaitu secara langsung dan secara tidak langsung. Tindak tutur secara langsung yaitu tindak tutur yang diungkapkan secara lugas (terus terang) dan apa adanya, sedangkan tindak tutur tidak langsung yaitu tindak tutur yang diungkapkan melalui (bentuk) tuturan lain.

Ketiga, ada tindak perlokusi (hatsuwa baikai koui). Tindak perlokusi adalah tindak tutur yang menumbuhkan pengaruh (effect) kepada mitra tutur. Tindak tutur ini disebut juga sebagai The Act of Affecting Someone (Searle dalam Leech, 1993).

\section{Strategi Mengeluh}

Dalam menyatakan keluhan, terdapat banyak strategi yang bisa digunakan oleh penutur, baik secara langsung maupun tidak langsung. Trosborg dalam Benning dan Parwati (2018) menyatakan bahwa terdapat 4 strategi mengeluh (No explicit reproach, Expression of annoyance or disapproval, Accusations, dan Blaming) yang kemudian dipecah menjadi 8 substrategi (Hints, Annoyance, Ill consequences, Indirect accusation, Direct accusation, Modified blame, Explicit Blame of the Accused's Action, dan Explicit Blame of the Accused as a Person.)

Tuturan mengeluh ke dalam 4 kategori direalisasikan ke dalam 8 strategi. Berikut penjelasan singkat masing-masing strategi mengeluh:

1. Keluhan Implisit (No explicit reproach)

Strategi mengeluh dengan keluhan implisit ini dilakukan dengan tidak menyebutkan hal yang dikeluhkan kepada mitra tutur supaya menghindari terjadinya konflik. Pernyataan yang dituturkan oleh penutur menyiratkan bahwa penutur mengetahui tentang tindakan yang terjadi merupakan tanggung jawab dari mitra tutur. Tindakan ini digolongkan ke dalam strategi kesatu, atau strategi yang paling lemah. Strategi pertama ini hanya terdapat satu sub strategi, yaitu Isyarat (Hint). Penutur menggunakan isyarat untuk menuturkan hal yang akan dikeluhkan kepada mitra tuturnya, sehingga mitra tutur bisa saja tidak menyadari bahwa keluhan tersebut ditujukan kepadanya. 
Contoh:

The kitchen was clean and orderly when I left it last. Dapur ini bersih dan teratur ketika aku meninggalkannya terakhir kali.

2. Ungkapan kekesalan/ ketidaksetujuan (Expression of disapproval)

Penutur mengekspresikan rasa tidak suka, kecewa maupun terganggu terkait hal yang dirasa buruk bagi penutur. Dalam strategi ini, dibagi menjadi dua sub strategi, yaitu:

a) Kekesalan (Annoyance)

Strategi kedua ini merupakan keluhan dengan menuturkan kekesalan. Penutur mengekspresikan kekesalan, menyampaikan kejengkelan, ketidaksukaan, dan sebagainya kepada situasi dan tindakan yang dianggap buruk bagi penutur tanpa menyebutkan bahwa mitra tutur harus bertanggung jawab atas keluhannya.

Contoh:

Look at these things, all over the place.

Lihat semua benda ini, di seluruh penjuru tempat ini.

b) Konsekuensi buruk (Ill consequency)

Strategi ketiga ini, merupakan strategi keluhan dengan menuturkan konsekuensi buruk. Penutur mengungkapkan konsekuensi buruk (ill consequency) yang telah terjadi kepada penutur di hadapan mitra tutur.

Contoh:

I have already spar, spa, I've already spent ten minutes oh, quarter of an hour I think it was, cleaning up the bathroom itself.

Aku sudah menghabiskan waktu hampir 10 menit, bahkan seperempat jam, membersihkan kamar mandi sendirian.

3. Tuduhan (Accusations)

Strategi ini dibedakan menjadi dua subkategori, yaitu:

b) Tuduhan tidak langsung (Indirect Accusation) Strategi keempat yaitu keluhan dengan mengungkapkan tuduhan secara tidak langsung. Penutur menggunakan kalimat tanya mengenai situasi yang dekat dengan hal yang dikeluhkan kepada mitra tutur dan dalam tuturan tersebut, penutur secara tidak langsung menyatakan bahwa mitra tutur ada hubungannya dengan situasi dan hal yang dikeluhkan oleh penutur.
Contoh:

Look what I just found in my cupboard, your dirty clothes.

Lihat yang kutemukan di lemariku, baju kotormu.

c) Tuduhan langsung (Direct Accusation)

Strategi kelima yaitu keluhan dengan tuduhan langsung. Strategi ini diungkapkan dengan cara langsung menuduh mitra tutur atas perilakunya yang merugikan penutur, karena menurut penutur dia memang bersalah ataupun melakukan tindakan yang buruk.

Contoh:

You don't even clean up after you when you've been there, you used to do it, what's up with you now?

Kamu bahkan belum merapikan apapun, semenjak kamu ada disana, padahal dulu kamu terbiasa membersihkannya, ada apa dengan dirimu sekarang?

4. Menyalahkan (Blaming)

Dalam strategi ini, penutur menyalahkan mitra tutur dalam keluhannya. Terdapat tiga subkategori strategi mengeluh yang digunakan oleh penutur dalam menuturkan keluhannya, yaitu:

a) Modifikasi ungkapan menyalahkan (Modified blame)

Strategi keenam ini merupakan strategi keluhan dengan modifikasi ungkapan menyalahkan. Dalam strategi ini, penutur mengekspresikan rasa tidak sukanya terhadap tindakan mitra tutur dengan mengubah atau memberikan alternatif tindakan yang diinginkan oleh penutur. Penutur menyampaikan modifikasi keluhannya atas tindakan yang mitra tuturlah sebagai pihak yang bertanggung jawab atau penutur menyatakan pilihan terhadap pendekatan alternatif yang tidak diambil oleh mitra tutur.

Contoh:

It's boring to stay here, and I hate living in a mess, anyway you ought to clean up after you.

Membosankan berada disini dan aku benci tinggal dalam kekacauan, ngomongngomong kamu harus membersihkan semua ini sendiri.

b) Menyalahkan secara eksplisit (sikap) (Explicit blame (behavior)) 
Strategi keenam ini merupakan strategi keluhan dengan menyalahkan secara eksplisit sikap mitra tutur. Dalam strategi ini, penutur menyatakan secara eksplisit bahwa tindakan atau sikap mitra tutur buruk dan tidak menyenangkan merupakan tanggung jawab dari mitra tutur.

Contoh:

You never clean up after you, I'm sick and tired of it.

Kamu tidak pernah membersihkan apapun, aku sudah muak dan capek dengan semua ini.

c) Menyalahkan secara eksplisit (orang) (Explicit blame (person)

Strategi keenam ini merupakan strategi keluhan dengan menyalahkan secara eksplisit kepada orang. Strategi ini disampaikan dengan cara penutur menyalahkan kepada diri mitra tutur sebagai manusia secara keseluruhan bukan pada tindakan yang telah dilakukan olehnya.

Contoh:

Mette, really, one can never trust you a damn. Sumpah, sungguh, semua orang tidak akan percaya padamu bajingan.

\section{METODE PENELITIAN}

Penelitian ini merupakan penelitian deskriptif kualitatif. Data dalam penelitian ini berupa tuturan yang mengandung tuturan mengeluh oleh tokoh anak-anak dalam film Stand by Me Doraemon. Lalu, sumber data yang digunakan adalah film yang berjudul Stand by Me Doraemon yang disutradarai oleh Ryūichi Yagi and Takashi Yamazaki dan dirilis pada tanggal 8 Agustus 2014.

Teknik pengumpulan data yang digunakan pada penelitian ini adalah teknik simak catat. Sumber data berasal dari transkrip percakapan berupa terjemahan percakapan yang mengandung ujaran keluhan.

Langkah-langkah analisis data yang dilakukan diantaranya mengklasifikasikan sumber data ke dalam strategi mengeluh Trosborg (1995), menganalisis bentuk tuturan keluhan dan melihat penggunaan strategi mengeluh yang paling banyak ditemukan dalam film Stand by Me Doraemon.

\section{HASIL \& PEMBAHASAN}

\section{Keluhan dengan Isyarat}

Penutur mengeluh tanpa mengucapkan keluhannya secara langsung kepada mitra tutur di dalam pernyataannya agar tidak menyinggung perasaan mitra tutur. Isi dari keluhan tidak terdapat dalam pernyataan yang diucapkan oleh penutur. Mitra tutur mungkin bisa atau tidak menyadari maksud ucapan yang dituturkan oleh penutur.

\begin{abstract}
Data (1)
Sekkaku mirai ga ii houkou ni natte kita no ni... a ! kono mama jya Shizuka chan no omukosan wa Dekisugi ni nacchau kamoshirenai !

Ketika masa depanku mulai berubah... Dia akhirnya mungkin akan menikah dengan Dekisugi.
\end{abstract}

(Stand by Me Doraemon, menit ke 00.44.08)

Data (1) berasal dari sebuah percakapan antara Nobita dan Doraemon di kamar Nobita, lalu Nobita menyampaikan keluhannya sembari menangis kepada Doraemon dengan keadaan menenteng kartu yang menunjukkan gambar bahwa di masa depan Nobita yang akan menikah dengan Shizuka berganti berulang kali menjadi gambar Jaiko setelah melihat Dekisugi dan Shizuka di lapangan yang sedang berlatih untuk drama Cinderella dengan adegan Dekisugi melamar Shizuka.

Nobita mengekspresikan apa yang dirasakannya, mengungkapkan perasaan yang tidak mengenakkan dan merugikan bagi dirinya kepada Doraemon. Nobita mengatakan "Sekkaku mirai ga ii kata houkou ni nattekita noni. Aa ? Konomama ja Shizukachan no omukosan wa Dekisugi ni natchau kamo shirenai ?'. Tuturan pertama terdapat partikel noni yang digunakan jika kenyataan yang dijelaskan pada kalimat kedua bertentangan dengan dugaan yang diharapkan oleh penutur berdasarkan fakta yang dinyatakan pada kalimat pertama. Ekspresi ini menunjukkkan perasaan kecewa, kaget, tidak puas, dan sebagainya karena kenyataan tidak sesuai dengan harapan penutur sebelumnya. Didukung dengan tuturan berikutnya yang mengandung Kandoushi, yaitu " $A a \sim$ ?" yang termasuk ke dalam jenis Kandou (perasaan) yang berarti ungkapan perasaan sedih. Dalam percakapan ini, Nobita merasa sedih dan kesal karena gambar yang ada di kartu masa 
depannya berubah, bukan lagi gambar Shizuka, melainkan Jaiko. Nobita menuturkan bahwa ketika masa depannya mulai berubah, Shizuka mungkin akan menikah dengan Dekisugi, sedangkan Nobita mengharapkan akan menikah dengan Shizuka dengan ramalan kartu masa depan yang diberikan oleh Doraemon. Nobita menyampaikan tuturan ini supaya mitra tutur melihat situasi tersebut dan mereka merasa bersalah.

Nobita menggunakan strategi "keluhan implisit" karena menganggap Doraemon mengetahui kesalahannya dan akan bertanggungjawab atas apa yang terjadi dengan Nobita walaupun Nobita tidak menuturkan keluhannya secara terang-terangan. Doraemon seharusnya mengerti dan bertanggungjawab karena awalnya Doraemon memberitahu Nobita bahwa Nobita akan menikah dengan Shizuka melalui kartu yang menunjukkan gambar Shizuka di layarnya. Pada data di atas, Nobita memberitahukan kepada Doraemon bahwa ia berharap di masa depan akan menikah dengan Shizuka.

\section{Data (2)}

Sorenanoni watashi no hou wa Papa ya Mama ni nanimo shite agerarenakatta wa.

Tapi aku, aku belum melakukan sesuatu untuk membalas budi.

(Stand by Me Doraemon, menit ke 00.52.08)

Percakapan pada data 2 di atas terjadi antara Shizuka dengan Ayahnya. Shizuka menghampiri ayahnya untuk pamit tidur karena esok hari ia akan menikah. Nobita dan Doraemon melihat muka Shizuka yang nampak sedih. Saat Shizuka berjalan ke luar ruangan, Doraemon mengeluarkan alat pemancar kejujuran dan mengarahkannya kepada Shizuka. Alat tersebut membuat seseorang yang memendam sesuatu ini mengatakan semuanya. Shizuka yang sebelumnya sudah berjalan menuju ke kamarnya untuk tidur, kembali ke ruangan di tempat ayahnya berada lalu mengatakan kepada ayahnya bahwa ia tidak ingin menikah. Ayah Shizuka kebingungan mendengar perkataan Shizuka, lalu Shizuka menjelaskan kepada Ayahnya bahwa Shizuka merasa Ayahnya akan kehilangan Shizuka jika Shizuka menikah. Shizuka merasa bahwa ia belum bisa membalas kebaikan Ayah dan Ibunya yang merawat Shizuka dengan baik hingga ia dewasa, sehingga ia berpikir untuk membatalkan pernikahannya.
Pada data 2 di atas, hubungan yang terjalin antara Ayah dan Shizuka adalah orangtua dengan anak perempuannya. Sehingga, hubungan mereka akrab. Shizuka menunjukkan keluhannya dengan mengatakan "Sorenanoni watashi no hou wa... Papa y a Mama ni nanimo shite agerarenakatta wa..." yang artinya "Tapi aku... aku belum melakukan sesuatu untuk membalas budi." Pada kalimat "Sorenanoni watashi no hou wa..." yang memiliki arti "Tapi aku..." terdapat partikel nanoni yang menunjukkan perasaan ketidakpuasan penutur, maka dari itu tuturan tersebut dikatakan sebagai tindak tutur mengeluh. Mengeluh merupakan ungkapan ketidakpuasan terhadap suatu hal yang mempengaruhi diri penutur dengan cara tidak menyenangkan. Kalimat selanjutnya yang diucapkan oleh Shizuka adalah "Papa ya Mama ni nanimo shite agerarenakatta wa...", yang artinya "Aku belum melakukan sesuatu untuk membalas Ayah dan Ibu", terdapat bentuk "nakatta" yang berasal dari bentuk halus/sopan "nai" dan berbentuk negatif lampau. Partikel akhir ta digunakan kepada keluarga, sahabat, dan teman akrab. Dalam hal ini, penutur menunjukkan hubungan mitra tutur dengan penutur sebagai orang yang dekat dengan penutur.

Berdasarkan hasil analisis tersebut, tuturan yang diucapkan oleh Shizuka merupakan tindak tutur mengeluh. Tindak tutur mengeluh terjadi karena adanya tindakan orang lain yang mempengaruhi diri penutur dan penutur menyampaikan kepada seseorang tentang situasi yang mempengaruhi penutur yang dianggap salah atau tidak memuaskan dan sebaiknya diselesaikan dengan penutur memberitahu bahwa ia sedang merasa sedih atau sakit, dan membuat protes secara formal kepada seseorang. Shizuka menjelaskan keluhannya mengenai dirinya sendiri kepada Ayahnya, ia merasa belum bisa membalas budi kepada kedua orang tuanya dan Shizuka merasa takut jika nanti ia menikah, Ayahnya akan merasa kehilangan Shizuka. Dalam mengungkapkan keluhannya tersebut, Shizuka menggunakan strategi keluhan dengan isyarat.

\section{Data (3)}

Sore ga... Puroguramu jo... mou ni do to kono jidai ni wa korarenai $n$ desu.

Tapi... program ini... tidak mengizinkanku kembali ke zaman ini.

(Stand by Me Doraemon, menit ke 01.13.38)

Percakapan data 3 ini terjadi di ruang tamu antara Doraemon, Papa, dan Mama Nobita. 
Doraemon sudah menyelesaikan misi dari Dekisugi untuk membuat Nobita bahagia agar Doraemon bisa kembali ke masa depan. Doraemon menjelaskan bahwa ia harus kembali ke masa depan saat esok hari, jika tidak ia akan mendapatkan masalah. Lalu ayah Nobita menawarkan untuk berkunjung kembali, tetapi Doraemon berkata bahwa program dari zaman Doraemon membuat ia tidak bisa kembali ke zaman tersebut lagi. Doraemon mengeluhkan hal tersebut kepada ayah Nobita.

Pada data 3 tersebut Doraemon mengatakan "Sore ga... Puroguramu jo... mou ni do to kono jidai ni wa korarenaindesu" yang artinya "Tapi... Program ini... Tidak mengizinkanku untuk kembali ke zaman ini". Kata "sore ga" memiliki arti "sebenarnya" menunjukkan keluhan Doraemon tentang keadaan yang harus ia hadapi walaupun ia tidak menginginkan hal tersebut terjadi. Berikutnya ia mengatakan "Puroguramu jo mou ni do to kono jidai wa korarenaindesu" yang artinya "Program ini tidak mengizinkanku untuk kembali ke zaman ini". Bentuk "korarenai" berasal dari bentuk negatif "kuru" yang berarti "tidak kembali". Lalu, diikuti dengan kata "ndesu" berasal dari bentuk "no desu" yang sering digunakan dalam bahas percakapan dan lebih formal. Bentuk ini mengandung perasaan yang "ingin" disampaikan penutur untuk menunjukkan atau menekankan alasan atau keterangan dalam konteks. Dalam hal ini, penutur menjelaskan bahwa ia tidak bisa kembali ke zaman tersebut walaupun disisi lain ia tetap bisa kembali ke zaman tersebut.

Keluhan yang dituturkan Doraemon merupakan kategori mengeluh secara tidak langsung, yaitu penutur menyampaikan keluhannya kepada mitra tutur yang tidak ada hubungannya dengan isi keluhan yang disampaikan oleh penutur. Penutur bisa mengeluhkan mengenai dirinya sendiri, sesuatu, atau seseorang yang tidak ada pada saat keluhan tersebut dituturkan. Penutur dapat menyampaikan keluhannya kepada orang ketiga. Doraemon mengeluhkan tentang keadaan yang harus ia terima kepada orang ketiga (Ayah Nobita) bahwa ia tidak bisa kembali ke zaman tersebut walaupun ia tidak menginginkannya.

Berdasarkan hasil analisis data di atas, tuturan Doraemon merupakan tindak tutur mengeluh karena ia menjelaskan keadaan atau konsekuensi yang harus ia terima walaupun ia tidak menginginkannya kepada Ayah Nobita (mitra tutur, orang ketiga). Strategi mengeluh yang digunakan oleh Doraemon adalah strategi keluhan implisit.

\section{Keluhan dengan Menyatakan Kekesalan/Konsekuensi Buruk}

Penutur mengeluh dengan cara mengungkapkan semua rasa kesalnya, ketidaksukaannya, ketidaksetujuannya melalui tuturannya kepada mitra tutur. Kesal menurut Kamus Besar Bahasa Indonesia mengacu kepada perasaan tidak senang dan tidak puas terhadap suatu hal. Dalam hal ini, penutur merasa tidak senang dan tidak puas atas perkataan maupun tindakan yang dilakukan oleh mitra tuturnya. Penutur juga mengungkapkan konsekuensi buruk yang harus ia terima sebagai akibat dari tindakan yang sebenarnya menjadi tanggung jawab mitra tutur.

\section{Data (4)}

Yappari yameyou yo. Itte mo muda da yo. Hentikan saja. Ini tidak akan berhasil.

(Stand by Me Doraemon, menit ke 00.03.32)

Percakapan terjadi antara Sobi dan Doraemon yang berasal dari masa depan. Mereka sedang melihat kegiatan sehari-hari Nobita melalui Time Terebi. Doraemon tidak setuju dengan keputusan Sobi yang ingin membantu Nobita agar masa depan Nobita menjadi lebih baik. Doraemon menganggap apa yang dilakukan Sobi tidak akan berhasil. Doraemon lebih memilih untuk menghentikan semuanya setelah melihat kegiatan dan tingkah laku Nobita melalui Time Terebi.

Pada data 4 tersebut, Doraemon mengatakan "Yappari yameyou yo. Itte mo muda da yo" yang artinya "Hentikan saja ini tidak akan berhasil." Tuturan ini merupakan reaksi Doraemon atas tindakan yang dilakukan oleh Sobi. Sobi ingin membantu Nobita agar masa depan Nobita tidak berantakan. Pada tuturan tersebut, terdapat sebuah penekanan. Kata yang menunjukkan sebuah penekanan tersebut terdapat pada partikel akhir $y o$. Lebih ditekankan pada tuturan yo tersebut karena mengandung sebuah keluhan yang kuat, dan ingin disampaikan oleh Doraemon. Tuturan yang digarisbawahi terdapat partikel akhir yo yang memiliki fungsi untuk menunjukkan suatu pernyataan yang memastikan (Chino, 2008, hal. 123). Selain itu partikel akhir yo digunakan untuk mempertegas sebuah tuturan. Dalam tuturan tersebut Doraemon bermaksud menekankan tuturannya dengan informasi yang ia dapat kepada Sobi, bahwa tindakan yang dilakukan Sobi untuk 
menolong Nobita akan sia-sia menurut Doraemon.

Doraemon menggunakan strategi "ketidaksetujuan dengan mengekspresikan kekesalan" karena menganggap tindakan yang dilakukan Sobi itu tidak menyenangkan atau jelek bagi Doraemon tanpa harus adanya pertanggungjawaban atas hal yang dilakukan oleh Sobi. Sobi yang ingin membantu Nobita agar masa depan Nobita tidak terpuruk dianggap melakukan hal yang sia-sia oleh Doraemon setelah melihat perilaku Nobita sehari-hari yang berantakan dan ceroboh.

\section{Data (5)}

Anna gasatsu na ko ga boku no... Aaa... Uso da! Kaere! Kaerettara kaere! Deteke ! Sonnna detarame shinjinaizo !

Istriku penindas seperti dia... Aaa... Kau bohong! Pergi! Pergi! Pergi dari sini! Aku tidak percaya padamu!

(Stand by Me Doraemon, menit ke 00.07.30)

Percakapan pada data 5 di atas, terjadi di kamar Nobita antara Nobita dengan Sobi. Setelah Sobi dan Doraemon memperkenalkan dirinya kepada Nobita, Sobi menjelaskan kepada Nobita bahwa Nobita akan menikah 19 tahun lagi dari sekarang. Nobita bertanya kepada Sobi, dengan siapa dia akan menikah. Lalu Sobi menunjukkan foto pernikahan dan menjelaskan bahwa Nobita akan menikah dengan Jaiko dari hidupnya yang sekarang. Nobita mengeluhkan keluhannya kepada Sobi karena ia tidak terima dengan penjelasan dari Sobi bahwa ia akan menikah dengan Jaiko.

Pada data 5 di atas, Nobita mengekspresikan apa yang dirasakannya, mengungkapkan perasaan yang tidak menyenangkan baginya dan perasaan yang tidak mengenakkan tersebut reaksi dari tuturan Sobi. Nobita mengatakan "Sonna detarame shinjinaizo", yang artinya "Pergi dari sini, aku tidak percaya padamu!". Tuturan ini bersifat tegas karena terdapat partikel zo pada tuturan tersebut. Kata yang menunjukkan keluhan dari Nobita kepada Sobi yaitu "shinjinaizo" yang memiliki arti "tidak percaya". Tuturan tersebut diucapkan oleh Nobita sebagai reaksi atas ucapan dari Sobi. Sobi menjelaskan kepada Nobita bahwa Nobita akan menikah dengan Jaiko dari masa sekarang, Nobita tidak terima dengan tindakan atau tuturan Sobi. Lalu didukung dengan tuturan "Uso da! Kaere! Kaerettara kaere! Deteke !" Oleh Nobita yang artinya "Kau bohong! Pergi! Pergi! Pergi dari sini!". Kata "uso da" memiliki arti "bohong" menunjukkan rasa kesal Nobita kepada Sobi.

Berdasarkan hasil analisis melalui tuturan "Sonna detarame shinjinaizo" dan "Uso da! Kaere! Kaerettara kaere! Deteke !" menunjukkan bahwa tuturan yang diucapkan Nobita adalah tindak tutur mengeluh. Tuturan tersebut dilakukan dengan strategi keluhan dengan menyatakan kekesalan.

\section{Data (6)}

Nobita kun o shiawase ni shinai kagiri... Mirai ni kaete... Korarenai!

Sampai kau membantu Nobita menemukan kebahagiaan... kau tidak bisa kembali ke masa depan.

(Stand by Me Doraemon, menit ke 00.08.48)

Percakapan pada data 6 di atas terjadi di kamar Nobita antara Sobi, Nobita, dan Doraemon. Sobi menjelaskan kepada Nobita bahwa di masa depan, hidup Nobita kacau. Nobita tidak bisa mendapatkan pekerjaan lalu Nobita mendirikan perusahaan sendiri, tetapi semua habis terbakar dan hutang-hutang Nobita membengkak. Setelah mendengarkan penjelasan dari Sobi, Nobita merasa menyebabkan masalah. Sobi berkata bahwa Nobita bisa mengubah nasibnya. Itu sebabnya Sobi dan Doraemon berada di zaman ini. Doraemon masih belum setuju dengan keputusan Sobi. Sobi menghukum Doraemon dengan hukuman Doraemon tidak bisa kembali ke masa depan sampai ia membantu Nobita menemukan kebahagiaan.

Pada data 6 di atas, Sobi mengekspresikan apa yang dirasakan olehnya, mengungkapkan perasaan tidak mengenakkan baginya dan perasaan tidak menyenangkan tersebut merupakan reaksi dari tuturan Doraemon. Sobi mengatakan "Nobita kun o shiawase ni shinai kagiri... Mirai ni kaette... Korarenai!" yang artinya "Sampai kau membantu Nobita menemukan kebahagiaan... Kau tidak bisa kembali ke masa depan!". Sobi menuturkan tuturan yang mengekspresikan kekesalannya kepada Doraemon ditekankan pada kata "korarenai" yang memiliki arti "tidak bisa pulang". Sobi menekankan kekesalan atau keluhannya kepada Doraemon dengan cara membuat Doraremon tidak bisa pulang ke masa depan jika tidak bisa menemukan kebahagiaan Nobita.

Berdasarkan hasil analisis, tuturan Sobi merupakan tindak tutur mengeluh. Sobi mengeluhkan tuturan dari Doremon yang tidak sesuai dengan kesepakatan awal bahwa mereka 
ingin membantu Nobita agar Nobita dapat memperbaiki masa depannya. Sobi membuat raut wajah yang kesal kepada Doraemon dan memberikan konsekuensi buruk yang harus Doraemon terima karena Sobi merasa Doraemon mengecewakan Sobi. Sobi menyampaikan keluhannya secara verbal dan langsung kepada mitra tutur yang dikeluhkannya.

\section{Keluhan dengan Menyatakan Tuduhan}

Penutur mengeluh terhadap situasi yang terjadi dengan cara menuduh mitra tutur secara langsung atau tidak langsung. Penutur menganggap bahwa mitra tutur adalah orang yang bertanggung jawab terhadap situasi yang tidak menyenangkan bagi penutur. Dalam keluhan dengan cara menyatakan tuduhan secara langsung, penutur dapat menuduh langsung kepada mitra tutur yang dianggap telah melakukan kesalahan atau tindakan buruk, sedangkan tuduhan secara langsung, oenutur dapat mengajukan pertanyaan kepada mitra tutur terkait situasi atau menyatakan bahwa dia ada hubungannya dengan peristiwa yang terjadi.

\section{Data (7)}

Hito no koto ienai darou!

Semua orang bisa membuat kesalahan!

(Stand by Me Doraemon, menit ke 01.03.36)

Percakapan di atas terjadi antara Doraemon dan Nobita di gedung pernikahan Nobita dari masa depan. Nobita dan Doraemon berencana melihat pesta pernikahan Nobita di masa depan. Setelah sampai di gedung pernikahan, Nobita bingung mengapa tidak ada pernikahan di hari tersebut, ternyata Doraemon salah memasukkan tujuan tanggal yang dituju. Pesta pernikahan dilaksanakan esok hari, sedangkan mereka datang ke gedung pernikahan pada hari ini. Nobita menyampaikan keluhannya kepada Doraemon yang membuat kesalahan.

Nobita mengatakan "Hito ni koto ienai darou!" yang artinya "Lihat? Semua orang melakukan kesalahan!". "Hito ni koto ienai" merupakan bentuk keluhan yang disampaikan oleh Nobita kepada Doraemon. Nobita menuduh Doraemon membuat kesalahan. Nobita berpikir bahwa semua orang pasti membuat kesalahan, jadi Doraemon pun pasti membuat kesalahan. Doraemon tidak sengaja membuat kesalahan, yaitu Doraemon salah memasukkan tujuan tanggal pernikahan Nobita di masa depan. Nobita dan Doraemon sedang berada di masa depan dan ingin melihat pesta pernikahan Nobita dengan Shizuka di masa depan, tetapi Doraemon melakukan kesalahan. Nobita menyampaikan keluhannya dengan strategi keluhan tuduhan secara langsung. Dilanjutkan dengan partikel darou di akhir kalimat. Partikel darou berfungsi untuk meminta persetujuan dari lawan bicara akan hal yang diperbincangkan dan intonasinya dinaikkan. Dalam bahasa Indonesia, polanya "bla bla bla, bukan?". Darou digunakan untuk orang lain, tidak untuk diri sendiri. Darou merupakan bentuk biasa dari deshou.

Berdasarkan hasil analisis, tuturan Nobita termasuk dalam tindak tutur mengeluh. Penutur mengungkapkan perasaan tidak senang terhadap tindakan yang sedang berlangsung. Oleh sebab itu, penutur menyampaikan keluhan secara verbal kepada mitra tuturnya. Keluhan ini ditunjukkan kepada mitra tutur yang dianggap penutur bertanggung jawab atas tindakan yang terjadi. Penutur menuduh langsung kepada mitra tutur yang dianggap telah melakukan kesalahan atau tindakan buruk. Tuturan mengeluh Nobita ini dilakukan dengan strategi keluhan dengan tuduhan secara langsung. Nobita menuduh Doraemon melakukan kesalahan.

\section{Keluhan dengan cara Menyalahkan}

Penutur mengeluh terhadap suatu situasi yang terjadi dengan cara menyalahkan mitra tutur. Penutur menganggap bahwa mitra tutur adalah orang yang harus bertanggung jawab terhadap situasi yang tidak menyenangkan dan dirasakan oleh penutur. Dalam keluhan dengan cara menyalahkan, penutur dapat menyalahkan tindakan yang diperbuat oleh mitra tuturnya maupun menyalahkan pada diri orang yang telah melakukan tindakan tersebut. Penutur juga dapat melakukan berbagai cara sebelum menyalahkan orang tersebut.

\section{Data (8)}

Nande motto hayaku okoshitekurenai no Mama!

Kenapa Ibu tidak membangunkanku lebih cepat?

(Stand by Me Doraemon, menit ke 00.01.22)

Percakapan ini terjadi di rumah Nobita antara Ibu dan Nobita. Ibu mencoba membangunkan Nobita untuk sekolah karena Nobita sudah kesiangan. Nobita terbangun mendengar teriakan dari Ibu pun langsung melihat jam yang berada di sebelahnya dan terkejut lalu mengeluhkan Ibu yang ia pikir tidak membangunkannya lebih cepat 
dan menyebabkan Nobita bangun kesiangan. Nobita menyalahkan Ibunya karena merasa Ibunya yang menyebabkan Nobita bangun kesiangan. Tetapi, Ibu Nobita tidak merasa bersalah karena sudah mencoba membangunkan berulang kali tetapi Nobita tetap tidak bangun.

Pada tuturan "Nande motto hayaku okoshite kurenaino" yang memiliki arti "Mengapa tidak membangunkanku lebih cepat?" Nobita mengungkapkan perasaan tidak menyenangkan atau keluhannya kepada Ibunya (mitra tutur). "Nande" merupakan bentuk informal dari "doushite" yang digunakan oleh Nobita karena ia berbicara kepada Ibunya sendiri sehingga menggunakan "nande" yang biasa digunakan untuk percakapan sehari-hari. Selanjutnya, terdapat kata "motto hayaku okoshite kurenai" yang artinya "tidak membangunkanku lebih cepat", secara langsung Nobita mengharapkan Ibunya membangunkan lebih cepat tetapi kenyataannya tidak sesuai dengan apa yang ia harapkan. Di akhir kalimat terdapat partikel " $n o$ " yang berfungsi menekankan sebuah pertanyaan. Tuturan dari data ini merupakan reaksi Nobita kepada Ibunya yang membuat Nobita merasa kesal, Ibu mencoba membangunkan Nobita yang kesiangan untuk sekolah, tetapi Nobita menyalahkan Ibunya karena tidak membangunkannya lebih cepat agar ia tidak terlambat untuk ke sekolah.

Nobita menggunakan strategi "menyalahkan secara tindakan" pada keluhannya, karena Nobita mengeluh dengan tindakan yang dilakukan Ibunya. Menurut Nobita, Ibunyalah yang harus bertanggungjawab atas keluhannya, maka dari itu Nobita menyalahkan secara langsung tindakan yang dilakukan Ibunya. Nobita "menyalahkan secara langsung (tindakan)" karena Ibunya yang menyebabkan ia kesiangan.

\section{Data (9)}

Hidoi puroguramu o zetto shite kureta mondayo mou... aite... kegashitenai kanaa

Aku tidak percaya Sobi mengaktifkan programnya. $\mathrm{Ku}$ harap aku tidak terluka...

(Stand by Me Doraemon, menit ke 00.10.39)

Percakapan di atas terjadi antara Doraemon dan Nobita di kamar Nobita. Doraemon diberikan tugas oleh Sobi untuk membantu Nobita menemukan kebahagiaan Nobita dan bisa pulang ke masa depan jika sudah menyelesaikan misi dari Sobi. Doraemon merasa tidak bisa melakukan misi dari Sobi dan ingin kembali ke masa depan. Program pendeteksi mendeteksi kata-kata yang tidak boleh diucapkan yaitu "ingin kembali", jika kata-kata tersebut diucapkan oleh Doraemon maka Doraemon mendapatkan sengatan sebagai bentuk hukuman dari program tersebut. Doraemon yang merasakan mendapatkan hukuman dari program tersebut, mengeluhkan Sobi yang ternyata telah mengaktifkan sistem program yang dibuat oleh Sobi.

Doraemon mengatakan "Sobi kun mo, hidoi puroguramo o zetto shite kureta mondayo mou... aite... kegashitenai kanaa." yang artinya "Aku tidak percaya Sobi mengaktifkan programnya. Ku harap aku tidak terluka...". Tuturan ini merupakan reaksi dari Doraemon atas tindakan yang dilakukan oleh Sobi. Kalimat "Sobi kun mo hidoi puroguramo o zetto shite kureta mondayo mou" merupakan tuturan keluhan yang disampaikan Doraemon untuk Sobi di hadapan Nobita. Doraemon menyalahkan tindakan Sobi, karena Doraemon tidak percaya bahwa Sobi telah mengaktifkan program yang dibuat oleh Sobi untuk Doraemon. Partikel "kanaa" memiliki arti "aku berharap" digunakan Doraemon untuk menyampaikan keluhannya kepada Sobi, Doraemon berharap ia tidak terluka dengan hukuman yang diberikan oleh program dari Sobi. Sobi membuat program misi untuk Doraemon yang mengharuskan Doraemon membantu Nobita menemukan kebahagiaan Nobita. Doraemon tidak bisa kembali ke masa depan jika misi tersebut belum selesai dan bila misi tersebut sudah selesai, Doraemon tidak bisa memilih untuk tetap tinggal di masa sekarang. Sobi memberikan hukuman di dalam program tersebut berupa sengatan ke tubuh Doraemon jika program tersebut mendeteksi kata "ingin kembali" dari Doraemon. Doraemon mengeluhkan Sobi yang sudah mengaktifkan programnya dan berharap agar ia tidak terluka jika terkena hukuman dari program Sobi tersebut. Suasana yang diciptakan Doraemon adalah Doraemon menggerutu sambil menahan rasa sakit dari sengatan program yang dibuat oleh Sobi. Doraemon menyampaikan keluhannya secara tidak langsung, yaitu melalui Nobita (orang ketiga).

Berdasarkan hasil analisis, tuturan Doraemon termasuk ke dalam tindak tutur mengeluh. Perbuatan Sobi menyebabkan konsekuensi yang tidak menyenangkan bagi penutur. Penutur menyampaikan keluhannya mengenai seseorang yang tidak ada pada saat keluhan tersebut dituturkan, dan penutur menyampaikan keluhannya kepada pihak ketiga. Doraemon menuturkan keluhannya kepada Nobita sebagai 
pihak ketiga, karena Sobi sebagai seseorang yang seharusnya bertanggung jawab dengan konsekuensi yang harus Doraemon terima, tidak ada pada saat keluhan tersebut dituturkan Doraemon. Tuturan mengeluh tersebut dilakukan dengan strategi keluhan dengan cara menyalahkan.

\section{Data (10)}

Ano hen tekona tamago de Doraemon no darou!?

Telur aneh itu milik Doraemon kan!?

(Stand by Me Doraemon, menit ke 00.24.44)

Percakapan di atas terjadi antara Suneo dan Nobita di halaman rumah Nobita. Nobita mendengar suara Suneo memanggil Nobita dari luar rumah. Nobita yang sedang sibuk menunggu Shizuka keluar dari telur menghampiri Suneo keluar dengan memasang muka kesal. Saat Nobita membuka pintu, Suneo menampakkan wajah yang panik dan terburu-buru. Suneo menyampaikan keluhannya mengenai telur milik Doraemon yang membuat ia merasa tidak senang karena Giant selalu mengikuti Suneo kemanapun Suneo pergi setelah Giant keluar dari telur milik Doraemon.

Suneo menggerutu di hadapan Nobita dan mengatakan "Ano hen tekona tamago de Doraemon no darou?" yang artinya "telur itu milik Doraemon, kan?". Suneo menciptakan suasana dengan muka yang panik dan terburu-buru. Partikel darou berfungsi untuk meminta persetujuan dari lawan bicara akan hal yang diperbincangkan dan intonasinya dinaikkan. Dalam bahasa Indonesia, polanya adalah "bla bla bla, bukan?". Darou digunakan untuk orang lain, tidak untuk diri sendiri. Darou merupakan bentuk biasa dari deshou. Suneo mengeluhkan kepada Nobita mengenai telur milik Doraemon yang membuat Giant menjadi mengejar-ngejar Suneo dan ia merasa terganggu dengan hal tersebut. Dilanjutkan dengan tuturan "Okage de hidoi me ni atterun da zo, nanto kashiru!" yang memiliki arti "Aku perlu bantuan, lakukan sesuatu!". Tuturan tersebut bersifat tegas karena adanya partikel $z o$ dalam tuturan tersebut. Suneo menegaskan bahwa ia butuh bantuan Nobita maupun Doraemon untuk melepaskan Giant dari dirinya. Suneo mengeluh secara tidak langsung karena ia mengeluhkan mengenai Doraemon yang tidak ada pada saat keluhan tersebut dituturkan dan menyampaikannya kepada Nobita sebagai pihak ketiga.

Berdasarkan hasil analisis dari data di atas melalui tuturan "Ano hen tekona tamago de
Doraemon no darou?" dan "Okage de hidoi me ni atterun da zo, nanto kashiru!" menunjukkan bahwa tuturan yang diucapkan oleh Suneo adalah tindak tutur mengeluh. Tuturan tersebut dilakukan dengan strategi keluhan dengan menyalahkan orang.

\section{Data (11)}

Doushite kurerun da yo are Mengapa kau biarkan ini terjadi

(Stand by Me Doraemon, menit ke 00.25.54)

Percakapan di atas terjadi antara Dekisugi, Nobita, dan Doraemon di kamar Nobita. Dekisugi berniat untuk menghampiri Shizuka ke rumahnya, tetapi saat ia sampai di halaman rumah Shizuka, Dekisugi masuk ke dalam "Lubang Ke Mana Saja" milik Doraemon yang sebenarnya digunakan untuk Shizuka oleh Nobita dan langsung terhubung ke kamar Nobita agar Shizuka langsung masuk ke dalam telur milik Doraemon. Dekisugi kebingungan melihat Shizuka keluar dari telur milik Doraemon dan langsung memeluk Dekisugi saat Shizuka melihat Dekisugi di depan matanya. Nobita yang baru membuka pintu kamarnya terkaget melihat Shizuka memeluk Dekisugi. Nobita menyampaikan keluhannya kepada Doraemon dengan cara menuturkan kekecewaan kepada Doraemon bahwa mengapa Doraemon membiarkan hal tersebut terjadi. Doraemon berkata bahwa ia sudah memberitahu kepada Nobita bahwa menggunakan alat seperti itu bukanlah ide yang bagus. Dekisugi meminta tolong kepada Nobita dan Doraemon untuk mengembalikan Shizuka menjadi normal kembali.

Nobita mengatakan "Doushite kurerun da yo are " yang artinya "Mengapa kau biarkan ini terjadi?". Kata "kurerun" menunjukkan suatu keluhan yang dituturkan oleh Nobita. Kureru memiliki arti "membiarkan" dan dilengkapi dengan partikel $n$ yang berfungsi menekankan tuturan tersebut kepada mitra tutur. Nobita berpikir bahwa Doraemon membiarkan hal buruk terjadi. Penutur menyatakan bahwa mitra tuturlah yang bersalah terhadap tindakan buruk yang terjadi. Tindakan buruk tersebut ditandai Nobita dengan kata "kurerun" yaitu "membiarkan". Tindakan buruk yang dimaksud oleh Nobita adalah ia melihat Shizuka memeluk Dekisugi yang seharusnya terjadi menurut Nobita adalah Shizuka jatuh cinta dan memeluk Nobita, Nobita berpikir Doraemon membiarkan hal buruk tersebut terjadi. Nobita mengeluh kepada Doraemon dengan wajah yang kecewa sembari menangis. 
Berdasarkan hasil analisis dari data di atas, tuturan Nobita termasuk ke dalam tindak tutur mengeluh. Penutur mengaharapkan Shizuka jatuh cinta dengan menggunakan telur milik Doraemon, namun harapan penutur tidak terjadi disebabkan oleh tindakan dari mitra tuturnya tersebut karena Nobita menganggap Doraemon membiarkan semuanya terjadi. Tindakan penutur yang membiarkan Shizuka salah sasaran menjadi Dekisugi dianggap penutur merugikan dirinya. Penutur memilih mengucapkan tuturan tersebut secara verbal. Tuturan verbal ini merupakan tuturan mengeluh. Tuturan mengeluh tersebut dilakukan dengan strategi keluhan dengan cara menyalahkan tindakan.

\section{Pembahasan}

Tokoh anak-anak pada anime ini sangat menggambarkan kondisi anak-anak pada umumnya yang tahap perkembangan emosinya masih labil, sehingga tuturan ketika menyatakan keluhan pun dikategorikan pada tindak tutur ekspresif yang betujuan untuk mengevaluasi atau memperbaiki suatu hal yang dianggap menandai sebuah kesulitan pada tuturan yang diujarkan (Rustono dalam Chamalah \& Turahmat, 2016).

Perkembangan psikologis dan juga mental pada anak-anak yang memang masih belum matang, menyebabkan tokoh anak dalam anime tersebut ketika mengalami kondisi yang dianggap tidak mengenakan, berupaya untuk mengutarakan maksud yang dirasakan dengan mengujarkannya melalui tindak tutur ilokusi berupa keluhan kepada tokoh lain yang berusia lebih tua maupun teman sebayanya. Hal ini sesuai dengan salah satu dari fungsi tindak tutur ilokusi yaitu untuk mengutarakan sikap psikologis seorang penutur terhadap kondisi sekitarnya (Ngusman, 2015).

Dalam sebuah situasi tuturan dalam anime tersebut, adanya perbedaan usia dari lawan tutur secara tidak langsung membuat penutur tokoh anak-anak menggunakan beberapa strategi mengeluh untuk menghindari terjadinya kesalahpahaman atau bahkan "menjatuhkan muka" penutur di hadapan lawan tuturnya (Ngusman, 2015). Strategi mengeluh yang dilakukan tokoh anak pada anime tersebut memiliki variasi pilihan strategi yang cukup beragam, akan tetapi umumnya strategi yang digunakan sangat mencirikan kondisi psikologis dari seorang anak, yang didominasi dengan strategi mengeluh berupa ekspresi kekesalan atau ketidaksetujuan, seperti yang diungkapkan oleh Trosborg dalam Benning dan Parwati (2018).

Tetapi yang menarik pada penelitian kali ini yaitu, tidak tampak ada pengaruh konsep uchi dan soto yang biasanya sangat kental dalam kehidupan bermasyarakat di Jepang. Hal ini terlihat dari pilihan strategi mengeluh dari tokoh anak-anak yang tidak menyiratkan secara langsung keluhan yang dirasakan, walaupun kepada tokoh yang sudah dianggap sebagai anggota keluarga sendiri. Bahkan beberapa strategi mengeluh yang dipilih dianggap "menyerang" lawan tutur dengan cara menyalahkan dan juga menunjukkan sebuah kekesalan yang diakibatkan dari konsekuensi buruk yang terjadi.

\section{KESIMPULAN}

Berdasarkan hasil analisis dan pembahasan pada bab 4, dalam film Stand by Me Doraemon terdapat 30 data mengenai keluhan oleh tokoh anak-anak kepada yang orang yang lebih tua maupun kepada teman sebaya. Terdapat empat strategi yang digunakan oleh tokoh anak-anak dalam film Stand by $\mathrm{Me}$ Doraemon, yaitu keluhan dengan isyarat, keluhan dengan menyatakan kekesalan/ketidaksetujuan, keluhan dengan menyatakan tuduhan, dan keluhan dengan cara menyalahkan.

Berdasarkan hasil analisis dan kesimpulan, strategi yang lebih banyak digunakan oleh tokoh anak-anak dalam film Stand by Me Doraemon adalah strategi keluhan dengan menyatakan kekesalan/konsekuensi buruk. Strategi yang dominan digunakan oleh tokoh anak-anak kepada orang yang lebih tua adalah keluhan implisit, sedangkan strategi yang dominan digunakan kepada anak-anak teman sebayanya adalah dengan menyatakan kekesalan/konsekuensi buruk.

\section{REFERENSI}

Aprianti, Y. (2018). Tindak Tutur Ilokusi Direktif "Memerintah" dalam Serial Drama Kodo Buru Dokuta Heri Kinkyu Kyumei (Skripsi, Universitas Jenderal Soedirman). Diakses dari https://apps.spmb.unsoed.ac.id/index.php?r=artik elilmiah/view\&id $=22798$

Benning, M. A., \& Parwati. (2018). Strategi tindak tutur mengeluh dengan menyalahkan tindakan dalam drama Suki na Hito ga Iru Koto. Japanology, 6(2), 154- 
166.

Diakses

http://repository.unair.ac.id/id/eprint/76367

Chaer, A. (2014). Linguistik Umum. Jakarta: Rineka Cipta.

Chamalah, E., \& Turahmat. (2016). Tindak tutur ekspresif pada bak truk sebagai alternatif materi ajar pragmatik. Jurnal Bahastra, 35 (2), 27-40. http://dx.doi.org/10.26555/bahastra.v35i2.4859

Chino, N. (2008). Partikel Penting Bahasa Jepang (Edisi Terjemahan oleh Nazir Ramli). Jakarta: Kesaint Blanc.

Leech, G. (1993). Prinsip-Prinsip Pragmatik (Edisi Terjemahan Oleh M. D. D. Oka). Jakarta: Penerbit Universitas Indonesia Press.

Nadar, F.X. (2008). Pragmatik \& Penelitian Pragmatik. Yogyakarta: Universitas Gadjah Mada.

Ngusman, W. A. (2015). Tindak tutur ekspresif Mario Teguh dalam acara "Golden Ways". Jurnal Bahasa, Sastra dan Pembelajaran, 2 (1), 99-113. Diakses dari https://jurnal.unimed.ac.id/2012/index.php/sasin do/article/view/1603/1311
Nurgiyantoro, B. (2002). Teori Pengkajian Fiksi. Yogyakarta: Gadjah Mada University Press.

Nurhasanah, G. (2010). Tindak Tutur Mengeluh dalam Bahasa Jepang. Universitas Indonesia.

Putrayasa, I. B. (2014). Pragmatik. Yogyakarta: Graha Ilmu.

Sutedi, D. (2011). Dasar-dasar Linguistik Bahasa Jepang. Bandung: Humaniora.

Trosborg, A. (1995). Interlanguage Pragmatics: Request, Complaints and Apologies. Berlin: Mouton de Gyuter.

Winoto, D. R., \& Artanto, B. (2012). Tindak Tutur Mengeluh Bahasa Jepang Studi Kasus dalam Film Great Teacher Onizuka (Skripsi, Universitas Dian Nuswantoro). https://doi.org/10.33633/lite.v14i1.1975

Yule, G. (1996). Pragmatics. New York: Oxford University Press.

苦情とクレームと文句と抗議. (2018). Diakses dari https://chigai-allguide.com/苦情とクレームと文 句と抗議/ 